\title{
Research of element composition of Verbena species
}

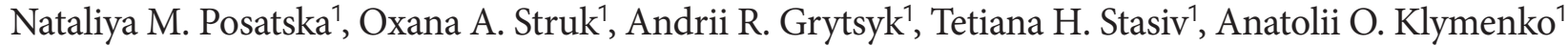 \\ 1 Ivano-Frankivsk State Medical University, Ivano-Frankivsk, Ukraine \\ Corresponding author: Oxana A. Struk (sanichka5@gmail.com)
}

Received 12 September 2019 Accepted 25 November 2019 Published 12 February 2021

Citation: Posatska NM, Struk OA, Grytsyk AR, Stasiv TH, Klymenko AO (2021) Research of element composition of Verbena species. Pharmacia 68(1): 227-233. https://doi.org/10.3897/pharmacia.68.e46513

\begin{abstract}
Violation of homeostasis is often connected with a deficiency or excess of certain elements. Undeniable value of biologically active substances of plants is that they are contained in plant raw material in natural balanced complexes and they are an important source of macro- and microelements for a human organism. Study of a chemical composition, including macro- and microelements, a pharmacological effect of Verbena species is a basis for conduction of further researches.

There are 250 species of Verbena genus, 3 of which, namely Verbena officinalis L., Verbena supina L. and Verbena hybrida Hort are growing in Ukraine.

The aim of our research was to study macro- and microelements in the raw material of Verbena genus species, to reveal the influence of the conditions of growing on the content of elements in the Verbena officinalis L. herb, to compare element composition of the Verbena officinalis L. herb and herbal extracts.

Macro- and microelement composition of raw material was researched by using the method of atom-emission spectrometry with inductively bounded plasma iCAP 7000 Duo. To determine the influence of the conditions of increase of macro- and microelements in Verbena officinalis L. herb, their quantity in soils and plants from different areas of growing was defined. To reveal the intensity of absorption of macro- and microelements from the soil by the plants, the coefficients of their biological accumulation were calculated. The comparative determination of the element composition of Verbena officinalis L. herb and herbal extracts VOH-0 (extractant purified water) and VOH-7 (extractant - 70\% ethanol) was also carried out to determine the degree of elements transfer from plant raw material into extracts.

Results of the research show that in the samples of Verbena officinalis L. herb, Verbena hybrida Hort. herb and Verbena supine L. leaves there are 22 inorganic elements. Results of studying of element composition of Verbena officinalis L. herb and samples of soil from different areas of growing in Ivano-Frankivsk and Ternopil regions show that the quantitative and qualitative compositions of microelements depend on element exchange of these plants, conditions of growing and element composition of soil. The reverse dependence between the content of most elements in the soil and the coefficient of their accumulation in plants was found out. Concentration of elements in the herb and extracts was identified to have the same profile, but the quantitative content of elements was different, which was influenced by the extractor (purified water, $70 \%$ ethanol). Results of our research are currently relevant; they should be taken into account in the development of new herbal medicines, which would have desirable pharmacological effect in the future.
\end{abstract}

\section{Keywords}

herb, extract, macro- and microelements, Verbena officinalis L., Verbena hybrida Hort., Verbena supina L. 


\section{Relevance}

Research of mineral composition of prospective species of plants is relevant nowadays as macro- and microelements influence biological effect of herbal medicines. Elements take part in biochemical processes of the human organism; specifically they are a constituent part of many enzymes. Mineral substances stimulate processes of tissue breathing, exchange of energy, hematopoiesis, immune responses, synthesis of biologically active substances, hormones, metabolism of proteins, carbohydrates, lipids, nucleic acids, and correct the level of radical-free processes in our organism. Depending upon the number in the organism elements are conventionally divided into macroelements, the concentration of which is $10 \%-0.001 \%$ of the body weight ( $60 \%$ of all cell elements), and microelements with a concentration of $0.001 \%-0.000001 \%$ of the body weight $(30 \%$ of all cell elements) (Kasi et al. 2010). Macro- and microelements, which are necessary for physiological processes in our organism are called essential (Bashkirova 2006). Macroelement $\mathrm{Mg}$ and microelements $\mathrm{Zn}, \mathrm{Cr}, \mathrm{Mn}$ and $\mathrm{Cu}$ are essential and take an active part in the regulation of hydrocarbohydrate metabolism (Markevych et al. 2010).

Violation of homeostasis is often connected with a deficiency or excess of certain elements (Kasi et al. 2010; Gupta et al. 2014; Nischwitz et al. 2014). Physiological value of microelements makes up a basis of their division in organs and tissues in our organism. Violation of breathing processes depends on the content of $\mathrm{Cu}$ and $\mathrm{Fe}$ in our organism, Mn and Fe influence the processes of hematopoiesis. Violation of immune system and depressions are typical symptoms of $\mathrm{Mn}, \mathrm{Fe}$ and Ni deficiency (Kvashnina et al. 2009).

Scientists researched that there is a connection between the content of macro- and microelements in plants, medical plant raw material, environment and frequency of some human diseases. The whole set of factors influence a human being; content of inorganic elements is only one of them. The value of biologically active substances is that they are contained in herbal raw material in naturally balanced complexes and are an important source of macroand microelements in a human organism (Gupta et al. 2014; Nischwitz et al. 2014; Perekhodko 2015). Chemical elements in plants are often connected with biologically active organic substances (enzymes, vitamins, hormones) and influence their biosynthesis. The researched natural concentrators of macro- and microelements among plants can be successfully used in medicine for corrective therapy (Kozyra et al. 2011; Shakya 2016).

Research of chemical composition, including macroand microelements, pharmacological activity of Verbena species is a basis for the conduction of research.

There are 250 species of Verbena genus, 3 of which, namely Verbena officinalis L., Verbena supina L. and Verbena hybrida Hort. grow in Ukraine (Hrodzinskyi 1990; Posatska et al. 2017).

Verbena officinalis L. herb is a perennial herbaceous rough-pubescent plant. The stem is quadrangular, erect and ascending, it grows up to $25-100 \mathrm{~cm}$, mostly branched. Leaves are $2-10 \mathrm{~cm}$ long, shortly stalked and oblong. Flowers are pale violet; they are divided into 5 petals, androgynous in long spiked inflorescence. Coriander is funnel-like; fruits are nuts. It blossoms from April till October. It grows in almost all territory of Ukraine in weeded areas, roadsides and wet sands (Markevych et al. 2010; Pohorielov et al. 2010). Verbena officinalis L. herb contains iridoids, terpenoids (lupeol, ursolic acid), steroids ( $\beta$-phytosterol), tannins, essential oil and vitamin C. This plant is famous for its therapeutic effect for gastrointestinal tract diseases, liver and spleen diseases, jaundice. Tincture is used for insomnia, nerve disorders, epilepsy, stones in kidneys and gall bladder.

Verbena hybrida Hort. is an annual herbaceous decorative plant, which grows up to $50 \mathrm{~cm}$. It has heavily branched lying stems, which are crept on earth. Inflorescence is spiky and consists of a few tens of flowers. The flowers are small in shields of white, dark blue or dark red color. Leaves are oblong, rough, notched and wooly, and are located opposite each other. Verbena hybrida Hort. blossoms for a long time and is a decoration of a garden or a lawn (Nesom 2010). Verbena hybrida Hort. herb contains tannins, essential oil, organic acids and vitamin C (Hrynkevych and Safronych 1983).

Verbena supine L. is a herbaceous plant with an erect, ramous stem roughened on edges, which grows up to $30-70 \mathrm{~cm}$. Leaves are ovate, oblong and roughened. Inflorescence is pale purple, oblong, spiky and thin. Fruit consists of 4 nuts. It blossoms from April till October. It grows in wet sandy areas, sometimes like a weed (Chrodzinskyi 1990; Posatska et al. 2017). Verbena supine L. contains tannins, essential oil, organic acids and vitamin C.

Pharmacological effect of Verbena hybrida Hort. and Verbena supine L. have not been studied yet.

This scientific research is a piece of scientific research work of the Pharmacy Department of IFNMU "Research of cultivated and wild medicinal plants of western Ukraine and development of technologies of their use with therapeutic purpose" (Number of state registration 0118U003809).

The aim of our research was to study the content of macro- and microelements in the raw material of Verbena genus species, to reveal the influence of growing conditions on the content of elements in Verbena officinalis L. herb and to conduct a comparative determination of the element composition of Verbena officinalis L. herb and herbal extracts VOH-0 (extractant - purified water) and VOH-7 (extractant - 70\% ethanol).

The objects of research were the herb of Verbena officinalis L. harvested in different areas in 2016-2017 (Ivano-Frankivsk region: Tysmenytsia district, village of Vovchyntsi; Kolomyia district, village of Vynohrad; Halych district, village of Zalukva; Ternopil region, Monastyrysk district, village of Honcharivka), the herb of Verbena hybrida Hort. harvested in 2017 (Ivano-Frankivsk region, Tysmenytsia district, village of Chukalivka); leaves of Verbena supine L. harvested in 2017 (Odessa region, 
Ovideopil district, village of Mykolayivka); samples of soil from the areas of growing of Verbena officinalis L. herb; Verbena officinalis L. herb extracts ( $\mathrm{VOH}-0, \mathrm{VOH}-7)$.

\section{Materials and methods}

Samples of raw material were harvested according to the procedures of storage of medicinal plant raw material. Absence of rain during 3-5 days before harvesting was a necessary condition (Trzhetsynskyi et al. 2015).

To determine macro- and microelements in the soil samples 10-20 spot tests were selected from the areas of growing of Verbena officinalis L. using the "envelope" method. Samples were taken from each layer at the depth from 0 to $5 \mathrm{~cm}$ and from 5 to $20 \mathrm{~cm}$, not more than $200 \mathrm{~g}$ each, using the instrument, which does not contain metals.

Macro- and microelement composition of raw material was studied in the State Enterprise "Ivano-Frankivsk scientific production centre of standardization, metrology and certification" (accreditation certificate No 2H098 dated 20.06.2014) using the method of atom emission spectrometry with inductively bounded plasma iCAP 7000 Duo.

Homogenization, weighing, adding of nitric acid and transfer of the appropriate sample to the microwave were done while preparing samples. Samples were decomposed under the influence of pressure and temperature. The sample received was diluted with deionized water and brought to atom emission spectrometer with inductively-bounded plasma, which includes computer-operated atom emission spectrometer with a background correction, radio frequency generator and a system of argon supply. Atom emission was measured by the method of optic spectroscopy. The sample was sprayed; the aerosol obtained was transferred to plasma burner, where excitation was taken place. Characteristic atom emission lines are generated by radio frequency inductively bounded plasma. The spectrum of measuring is distributed to the diffraction grate of spectrometer. The intensity of lines was registered by the detector. Detector signals were controlled and processed by the computer system (DSTU ISO 2007; Maliuvanchuk et al. 2018).

To reveal the influence of the growing conditions on the content of macro- and microelements of the Verbena officinalis L. herb their quantitative determination in soils and plants from various areas of growing was conducted. The content of mobile forms of macro- $(\mathrm{Mg}, \mathrm{Fe})$ and $\mathrm{mi}-$ croelements $(\mathrm{Cu}, \mathrm{Zn}, \mathrm{Mn}, \mathrm{Co}, \mathrm{Cr}, \mathrm{B}$ and $\mathrm{Cd})$ was determined in the selected samples. These elements were chosen because most of them are elements-biophylls, which are important for the plants (Pasichnyk et al. 2011).

To find out the intensity of absorption of macro- and microelements from the soil by the plants the coefficient of their biological accumulation (CBA) was calculated by the formula:

$\mathrm{CBA}=\frac{\text { content of element in the sample of medical plant raw material, } \mathrm{mg} / \mathrm{kg}}{}$ content of element in the soil, $\mathrm{mg} / \mathrm{kg}$
We can make a conclusion about the absorption of macro- and microelements from soils by the plants taking into account the coefficient of biological accumulation: CBA $<1$ means a low level of absorption of a certain element by the plant from the soil (Pasichnyk et al. 2011).

All the material was studied statistically according to the requirements of the State Pharmacopoeia of Ukraine by the method of variation statistics taking into account arithmetic mean and its standard error. Authenticity of the values compared was assessed by the Student's criteria and the level of probability was determined as $\mathrm{p} \leq 0.05$ (State Pharmacopeia 2015).

\section{Results and discussion}

Results of the research of the content of macro- and microelements in the raw material of Verbena species harvested in different areas are shown in Table 1.

Results of the research in Table 1 indicate that the samples of the Verbena officinalis L. herb, Verbena hybrida Hort. herb and Verbena supine L. leaves contain 22 inorganic elements, among which are macro- $(\mathrm{K}, \mathrm{Ca}, \mathrm{P}, \mathrm{Mg}$, $\mathrm{Na}, \mathrm{Fe}$ ) and microelements ( $\mathrm{Mn}, \mathrm{Zn}, \mathrm{Cu}, \mathrm{Cr}, \mathrm{Co}, \mathrm{Mo}$ ). The quantity of 18 inorganic elements was determined.

Verbena genus species accumulate a great amount of such inorganic elements as $\mathrm{K}, \mathrm{Ca}, \mathrm{P}$ and $\mathrm{Mg}$, which play an important role for the livelihood of living organisms. The highest content of $\mathrm{K}$ was in Verbena officinalis L. herb harvested in Ivano-Frankivsk region, Tysmenytsia district, village of Vovchyntsi - $5526.24 \mathrm{mg} / \mathrm{kg}$. The content of $\mathrm{K}$ in Verbena officinalis L. herb ranged from $5016.45 \mathrm{mg} / \mathrm{kg}$ to $5526.24 \mathrm{mg} / \mathrm{kg}$ of dry raw material, depending upon the area of growing. The content of $\mathrm{K}$ in Verbena hybrida Hort. herb was $5106.34 \mathrm{mg} / \mathrm{kg}$. The content of $\mathrm{Ca}$ in Verbena officinalis L. herb was from $3450.36 \mathrm{mg} / \mathrm{kg}$ to $3572.19 \mathrm{mg} / \mathrm{kg}$ of dry raw material. The content of $\mathrm{Ca}$ in Verbena hybrida Hort. herb was $3541.32 \mathrm{mg} / \mathrm{kg}$ of dry raw material. The highest content of $\mathrm{P}$ and $\mathrm{Mg}$ was observed in Verbena officinalis L. herb harvested in Ivano-Frankivsk region, Tysmenytsia district, village of Vovchyntsi and it was $2636.87 \mathrm{mg} / \mathrm{kg}$ and $1025.46 \mathrm{mg} / \mathrm{kg}$ of dry raw material relatively. The content of $\mathrm{Si}$ in the herb of Verbena species was from $143.36 \mathrm{mg} / \mathrm{kg}$ to $151 \mathrm{mg} / \mathrm{kg}$ of dry raw material. The highest content of $\mathrm{Na}$ was observed in Verbena officinalis L. herb (from $126.84 \mathrm{mg} / \mathrm{kg}$ to $134.16 \mathrm{mg}$ / $\mathrm{kg}$ of dry raw material). The content of $\mathrm{Al}$ in the herb of Verbena species was from $41.78 \mathrm{mg} / \mathrm{kg}$ to $46.04 \mathrm{mg} / \mathrm{kg}$ of dry raw material. The highest content of Mn was observed in Verbena officinalis L. herb harvested in Ivano-Frankivsk region, Halych district, village of Zalukva $(8.02 \mathrm{mg} / \mathrm{kg})$. The content of B in Verbena officinalis L. herb was from $7.66 \mathrm{mg} / \mathrm{kg}$ to $8.06 \mathrm{mg} / \mathrm{kg}$ of dry raw material. The content of Fe in Verbena officinalis L. herb was from $6.94 \mathrm{mg} / \mathrm{kg}$ to $7.56 \mathrm{mg} / \mathrm{kg}$, in Verbena hybrida Hort. herb $-3.76 \mathrm{mg} / \mathrm{kg}$ of dry raw material.The highest content of $\mathrm{Zn}$ was revealed in Verbena officinalis L. herb $(7.51 \mathrm{mg} / \mathrm{kg}$ of dry raw material). The content of $\mathrm{Ba}$ in the herb of Verbena spe- 
Table 1. Content of macro- and microelements in the raw material of Verbena species from different areas of growing.

\begin{tabular}{|c|c|c|c|c|c|c|}
\hline \multirow{2}{*}{$\begin{array}{l}\text { Name of } \\
\text { element }\end{array}$} & \multicolumn{4}{|c|}{ Herb of Verbena officinalis $\mathrm{L}$. } & \multirow{2}{*}{$\begin{array}{c}\text { Herb of Verbena hybrida } \\
\text { Hort. } \\
\text { Ivano-Frankivsk region, } \\
\text { Tysmenytsia district, } \\
\text { village of Chukalivka, } \\
2017\end{array}$} & \multirow{2}{*}{$\begin{array}{c}\text { Leaves of Verbena } \\
\text { supine } \mathrm{L} . \\
\text { Odessa region, Ovidiopil } \\
\text { district, village of } \\
\text { Mykolayivka, } 2017\end{array}$} \\
\hline & $\begin{array}{l}\text { Ivano-Frankivsk region, } \\
\text { Tysmenytsia district, } \\
\text { village of Vovchyntsi, } \\
2017\end{array}$ & $\begin{array}{l}\text { Ivano-Frankivsk region, } \\
\text { Kolomyia district, village } \\
\text { of Vynohrad, } 2016\end{array}$ & $\begin{array}{c}\text { Ivano-Frankivsk region, } \\
\text { Tysmenytsia district, } \\
\text { village of Zalukva, 2017 }\end{array}$ & $\begin{array}{c}\text { Ternopil region. } \\
\text { Monastyrysk district, } \\
\text { village of Honcharivka, } \\
2017\end{array}$ & & \\
\hline & \multicolumn{6}{|c|}{$\mathrm{mg} / \mathrm{kg}$ of raw material } \\
\hline K & 5526.24 & 5499.73 & 5016.45 & 5498.17 & 5106.34 & 5311.26 \\
\hline $\mathrm{Ca}$ & 3473.07 & 3572.19 & 3518.34 & 3450.36 & 3541.32 & 3402.15 \\
\hline $\mathrm{P}$ & 2636.87 & 2514.21 & 2454.82 & 2520.11 & 1534.61 & 1795.45 \\
\hline $\mathrm{Mg}$ & 1025.46 & 1016.24 & 999.98 & 1001.97 & 882.21 & 881.31 \\
\hline $\mathrm{Si}$ & 145.95 & 146.70 & 144.73 & 143.36 & 151.00 & 149.69 \\
\hline $\mathrm{Na}$ & 134.16 & 129.56 & 126.84 & 131.19 & 79.26 & 107.54 \\
\hline $\mathrm{Al}$ & 41.78 & 46.04 & 44.38 & 42.12 & 44.37 & 30.89 \\
\hline $\mathrm{Mn}$ & 7.86 & 7.98 & 8.02 & 7.54 & 4.92 & 5.84 \\
\hline B & 7.91 & 8.06 & 7.66 & 7.84 & 4.96 & 5.88 \\
\hline $\mathrm{Fe}$ & 7.22 & 7.56 & 7.01 & 6.94 & 3.76 & 4.82 \\
\hline $\mathrm{Zn}$ & 7.25 & 7.49 & 7.11 & 7.51 & 5.11 & 3.63 \\
\hline $\mathrm{Ba}$ & 4.33 & 4.46 & 4.32 & 4.36 & 4.01 & 3.32 \\
\hline $\mathrm{Cu}$ & 3.01 & 2.94 & 2.98 & 3.06 & 1.89 & 2.24 \\
\hline $\mathrm{Cr}$ & 0.28 & 0.28 & 0.28 & 0.28 & 0.19 & 0.22 \\
\hline $\mathrm{Se}$ & 111.32 & 111.23 & 110.34 & 109.11 & 113.33 & 106.34 \\
\hline Co & 35.00 & 35.10 & 35.55 & 34.76 & 31.23 & 33.12 \\
\hline $\mathrm{Sr}$ & 15.92 & 16.08 & 16.65 & 15.32 & 17.90 & 16.93 \\
\hline Mo & 15.40 & 15.10 & 15.12 & 15.18 & 15.04 & 14.01 \\
\hline $\mathrm{Cd}$ & 0.002 & 0.002 & 0.002 & 0.002 & 0.002 & 0.002 \\
\hline $\mathrm{Be}$ & $<0.002$ & $<0.002$ & $<0.002$ & $<0.002$ & $<0.002$ & $<0.002$ \\
\hline $\mathrm{Ni}$ & $<0.002$ & $<0.002$ & $<0.002$ & $<0.002$ & $<0.005$ & $<0.003$ \\
\hline I & $<0.002$ & $<0.002$ & $<0.002$ & $<0.002$ & $<0.002$ & $<0.002$ \\
\hline
\end{tabular}

cies was from $4.01 \mathrm{mg} / \mathrm{kg}$ to $4.46 \mathrm{mg} / \mathrm{kg}$ of raw material. The content of $\mathrm{Cu}$ in Verbena officinalis L. herb was from $2.94 \mathrm{mg} / \mathrm{kg}$ to $3.6 \mathrm{mg} / \mathrm{kg}$ of dry raw material. The content of $\mathrm{Cr}$ in Verbena herb was from $0.19 \mathrm{mg} / \mathrm{kg}$ to $0.28 \mathrm{mg} /$ $\mathrm{kg}$. The highest content of Se was found out in Verbena hybrida Hort. herb ( $113.33 \mu \mathrm{g} / \mathrm{kg}$ of dry raw material). The biggest content of Co was reveled in Verbena officinalis L. herb $(35.55 \mu \mathrm{g} / \mathrm{kg}$ of dry raw material). The content of $\mathrm{Sr}$ and Mo in the herb of Verbena species was from $15.92 \mu \mathrm{g} /$ $\mathrm{kg}$ to $17.90 \mu \mathrm{g} / \mathrm{kg}$ and from $15.04 \mu \mathrm{g} / \mathrm{kg}$ to $15.40 \mu \mathrm{g} / \mathrm{kg}$ of dry raw material relatively.

The highest content of $\mathrm{K}$ was revealed in the leaves of Verbena supine L., which was $5311.26 \mathrm{mg} / \mathrm{kg}$. The content of $\mathrm{Ca}$ was $3402.15 \mathrm{mg} / \mathrm{kg}$ of dry raw material. The content of $\mathrm{P}$ in the leaves of Verbena supine L. was $1795.45 \mathrm{mg} / \mathrm{kg}$. The content of $\mathrm{Mg}$ was determined as $881.31 \mathrm{mg} / \mathrm{kg}$ of dry raw material. The content of $\mathrm{Si}$ and $\mathrm{Na}$ in the leaves of Verbena supine $\mathrm{L}$. was $149.69 \mathrm{mg} / \mathrm{kg}$ and $107.54 \mathrm{mg} / \mathrm{kg}$ of dry raw material relatively. The content of Fe in the leaves of Verbena supine L. was $4.82 \mathrm{mg} / \mathrm{kg}$. The content of $\mathrm{Zn}, \mathrm{Ba}$ and $\mathrm{Cu}$ was $3.63 \mathrm{mg} / \mathrm{kg}, 3.32 \mathrm{mg} / \mathrm{kg}$ and $2.24 \mathrm{mg} / \mathrm{kg}$ relatively.

In the researched samples of Verbena species traces of I, $\mathrm{Be}$ and $\mathrm{Ni}$ were found out.

The content of heavy metals in the researched samples was within the allowed limits (SPU 2.0-2.4.27).

The quantitative content of macro- and microelements in the researched samples of raw material of Verbena species corresponds following regularities: $\mathrm{K}>\mathrm{Ca}>\mathrm{P}>\mathrm{Mg}>$ $\mathrm{Si}>\mathrm{Na}>\mathrm{Al}>\mathrm{Mn}>\mathrm{B}>\mathrm{Fe}>\mathrm{Zn}>\mathrm{Ba}>\mathrm{Cu}>\mathrm{Cr}$ and $\mathrm{Se}>\mathrm{Co}>$ $\mathrm{Sr}>\mathrm{Mo}>\mathrm{Cd}>\mathrm{Be}>\mathrm{Ni}>\mathrm{I}$.

As a result of the conducted research it was determined that the level of macro- and microelements is higher in the herb of Verbena officinalis L. than in the herb of Verbena hybrida Hort.

Results of the research of macro- and microelements content in the soils and in the herb of Verbena officinalis L. from different areas of growing are shown in Table 2.

The content of macro- and microelements (Table 2) in the herb of Verbena officinalis L. harvested in different areas of growing does not differ significantly. In all samples of the herb a high content of $\mathrm{Mg}$ and minor fluctuations of the level of other elements were identified, which shows absence of the influence of the area of plants growing on the quantitative content of elements in the raw material.

The rate of biological accumulation of macro- and microelements by the plants from the soil is shown in Table 3 .

The results in Table 3 show the reverse dependence of the content of most elements in the soil and the rate of their accumulation in plants.

The comparative analysis of the content of elements in the soils picked up in different areas of Verbena officinalis L. growing and CBA of these elements in the herb allowed us to determine peculiarities of dependence between these indicators.

We determined that if $\mathrm{Mg}$ indicator was low in all samples of soil, plants accumulated a big amount of these elements. CBA was from 14.36 to 20.51 depending upon the area of growing.

The content of $\mathrm{Mn}, \mathrm{Zn}, \mathrm{Fe}, \mathrm{Ba}, \mathrm{Cu}, \mathrm{Cr}$ and $\mathrm{Cd}$ in soils from different places of storing was much higher than in the samples of plants. CBA of these elements was below 1, which shows a low level of absorption of these elements by the plants from the soil. The content of B and Co in plants is much higher than in the soil samples, which means ac- 
Table 2. Quantitative content of elements in the soils and in the Verbena officinalis L. herb.

\begin{tabular}{|c|c|c|c|c|c|c|c|c|}
\hline \multirow{3}{*}{$\begin{array}{c}\text { Name of the } \\
\text { element }\end{array}$} & \multicolumn{8}{|c|}{ The Verbena officinalis L. herb } \\
\hline & \multicolumn{2}{|c|}{$\begin{array}{l}\text { Ivano-Frankivsk region, Tysmenytsia } \\
\text { district, village of Vovchyntsi, } 2017\end{array}$} & \multicolumn{2}{|c|}{$\begin{array}{l}\text { Ivano-Frankivsk region, Kolomyia } \\
\text { district, village of Vynohrad, } 2016\end{array}$} & \multicolumn{2}{|c|}{$\begin{array}{l}\text { Ivano-Frankivsk region, Tysmenytsia } \\
\text { district, village of Zalukva, } 2017\end{array}$} & \multicolumn{2}{|c|}{$\begin{array}{l}\text { Ternopil region, Monastyrysk district, } \\
\text { village of Honcharivka, } 2017\end{array}$} \\
\hline & herb & soil & herb & soil & herb & soil & herb & soil \\
\hline & \multicolumn{8}{|c|}{$\mathrm{mg} / \mathrm{kg}$ of the sample examined } \\
\hline $\mathrm{Mg}$ & 1025.46 & 71.39 & 1016.24 & 51.15 & 999.98 & 48.76 & 1001.97 & 66.29 \\
\hline $\mathrm{Mn}$ & 7.87 & 12.34 & 7.98 & 10.88 & 8.02 & 12.51 & 7.54 & 9.11 \\
\hline $\mathrm{Zn}$ & 7.25 & 58.80 & 7.49 & 46.70 & 7.11 & 52.43 & 7.51 & 56.33 \\
\hline $\mathrm{Fe}$ & 7.22 & 46.30 & 7.56 & 38.78 & 7.01 & 41.56 & 6.94 & 40.38 \\
\hline $\mathrm{Ba}$ & 4.33 & 62.18 & 4.46 & 57.16 & 4.32 & 61.22 & 4.36 & 66.45 \\
\hline $\mathrm{Cu}$ & 3.01 & 6.10 & 2.94 & 8.24 & 2.98 & 5.78 & 3.06 & 4.58 \\
\hline $\mathrm{Cr}$ & 0.28 & 21.25 & 0.28 & 16.56 & 0.28 & 18.67 & 0.28 & 20.44 \\
\hline B & 7.91 & 0.81 & 8.06 & 0.72 & 7.66 & 0.78 & 7.84 & 0.83 \\
\hline Co & 35.00 & 1.30 & 35.10 & 1.46 & 35.55 & 1.42 & 34.76 & 2.1 \\
\hline $\mathrm{Cd}$ & 0.002 & 1.74 & 0.002 & 1.65 & 0.002 & 1.43 & 0.002 & 1.58 \\
\hline
\end{tabular}

Table 3. The rate of biological accumulation of elements in the herb of Verbena harvested in different areas.

\begin{tabular}{|c|c|c|c|c|}
\hline \multirow{2}{*}{$\begin{array}{c}\text { Name of the } \\
\text { element }\end{array}$} & \multicolumn{4}{|c|}{ BAS } \\
\hline & $\begin{array}{l}\text { Ivano-Frankivsk region, Tysmenytsia } \\
\text { district, village of Vovchyntsi }\end{array}$ & $\begin{array}{l}\text { Ivano-Frankivsk region, Kolomyia } \\
\text { district, village of Vynohrad }\end{array}$ & $\begin{array}{l}\text { Ivano-Frankivsk region, Tysmenytsia } \\
\text { district, village of Zalukva }\end{array}$ & $\begin{array}{c}\text { Ternopil region. Monastyrysk district, } \\
\text { village of Honcharivka }\end{array}$ \\
\hline $\mathrm{Mg}$ & 14.36 & 19.87 & 20.51 & 15.12 \\
\hline $\mathrm{Mn}$ & 0.64 & 0.73 & 0.64 & 0.83 \\
\hline $\mathrm{Zn}$ & 0.12 & 0.16 & 0.14 & 0.13 \\
\hline $\mathrm{Fe}$ & 0.16 & 0.20 & 0.17 & 0.17 \\
\hline $\mathrm{Ba}$ & 0.07 & 0.08 & 0.07 & 0.07 \\
\hline $\mathrm{Cu}$ & 0.49 & 0.36 & 0.16 & 0.67 \\
\hline $\mathrm{Cr}$ & 0.01 & 0.02 & 0.2 & 0.01 \\
\hline B & 9.77 & 11.19 & 9.58 & 9.45 \\
\hline Co & 26.92 & 24.04 & 25.04 & 16.55 \\
\hline $\mathrm{Cd}$ & 0.001 & 0.001 & 0.001 & 0.001 \\
\hline
\end{tabular}

cumulation of these elements from the soil. CBA for B was from 9.45 to 11.19 depending upon the area of storing, and for Co - from 16.55 to 26.92 .

Based on the conducted research we can make a conclusion that in different conditions of growing plants absorb biochemical elements from the soil on which they grow, and also they can absorb a certain element in its high concentration in the soil with certain limits.

We compared the element composition of the Verbena officinalis L. herb and herbal extracts VOH-0 (extractant - purified water) and VOH-7 (extractant - 70\% ethanol) to determine the transition of elements from plant raw material to extracts.

The content of the given elements in the herb and extracts VOH-0 and VOH-7 is shown in Table 4.

Results of research shown in Table 4 indicate that the concentration of elements in the herb and extracts had the same profile, but we found out quantitative divergences of elements in extracts, which depend on the type of an extractor (purified water, ethanol 70\%).

Extracts VOH-0 and VOH-7 which have been researched have the highest content of $\mathrm{K}(4698.67 \mathrm{mg} / \mathrm{kg}$ and $2036.31 \mathrm{mg} / \mathrm{kg}$ relatively). The content of $\mathrm{Na}$ was $134.16 \mathrm{mg} / \mathrm{kg}$ in VLT-0 and $72.36 \mathrm{mg} / \mathrm{kg}$ in VLT-7.

Macro- and microelements are not synthesized in human organisms, and their balance is supported by the food products. Ideally, daily ration has to meet the needs of the organism, but as scientists state, the number of minerals in food products is different and is not always sufficient (Pohorielov et al. 2010).
Table 4. Element composition of Verbena officinalis L. herb and herbal extracts.

\begin{tabular}{lccc}
\hline Name of the element & Verbena officinalis $\mathbf{L}$. herb & VOH- 0 & VOH-7 \\
\hline \multicolumn{4}{c}{$\mathrm{mg} / \mathrm{kg}$ of the sample examined } \\
$\mathrm{K}$ & 5526.24 & 4698.67 & 2036.31 \\
$\mathrm{Ca}$ & 3473.07 & 2560.37 & 928.56 \\
$\mathrm{P}$ & 2636.87 & 2309.24 & 1796.8 \\
$\mathrm{Mg}$ & 1025.46 & 979.12 & 678.56 \\
$\mathrm{Na}$ & 134.16 & 72.36 & 108.55 \\
$\mathrm{Mn}$ & 7.87 & 6.79 & 2.54 \\
$\mathrm{Zn}$ & 7.25 & 3.65 & 4.48 \\
$\mathrm{Fe}$ & 7.22 & 4.63 & 1.28 \\
$\mathrm{Co}$ & 35.00 & 2.09 & 1.64 \\
$\mathrm{Cd}$ & 0.0002 & - & - \\
\hline
\end{tabular}

Thus, the given research shows that extracts $\mathrm{VOH}-0$ and $\mathrm{VOH}-7$ are valuable herbal medicines, as the correlation of $\mathrm{K} / \mathrm{Na}$ is observed, which is actual to reduce hypertensions in patients, who have high blood pressure. Both extracts $\mathrm{VOH}-0$ and $\mathrm{VOH}-7$ have a high content of $\mathrm{Ca}(2560.37 \mathrm{mg} /$ $\mathrm{kg}$ and $2036.31 \mathrm{mg} / \mathrm{kg}$ relatively). Therefore, extracts can be a source of $\mathrm{Ca}$ for bones strengthening, for rachitis, bad growth, for the reduction of blood coagulation and for vasodilatation. Extracts $\mathrm{VOH}-0$ and $\mathrm{VOH}-7$ are rich in $\mathrm{Mg}$ (979.12 mg/kg and $678.56 \mathrm{mg} / \mathrm{kg}$ relatively). Insufficient consumption of $\mathrm{Mg}$ causes biochemical deviations and development of ischemia, deficiency of skeletal growth, osteoporosis. The content of $\mathrm{P}$ in extracts is significant enough: VOH-0 - 2309.24 mg/kg, VOH-7 - $1796.8 \mathrm{mg} / \mathrm{kg}$. P plays an important role for living organism, ensures normal growth of a bone tissue, mental development. Daily need 
of $\mathrm{P}$ for adults amounts to $1200 \mathrm{mg}$. Extract VOH- 0 contains a higher concentration of elements than the extract $\mathrm{VOH}-7$, except for $\mathrm{Zn}$. Content of $\mathrm{Mn}$ and Fe is higher in $\mathrm{VOH}-0$ (6.79 mg/kg and $4.63 \mathrm{mg} / \mathrm{kg}$ relatively). Mn increases enzymes in our organism (carboxylases), participates in bones development. Fe is crucial for immune and biological processes, it stimulates efficient work of muscles during physical activity; it is a component of many protein and enzyme systems of our organism.

\section{Conclusions}

1. Macro- and microelement composition of Verbena species raw material was researched for the first time. 22 inorganic elements were identified. It was determined that the content of macro- and microelements in Verbena species corresponds following regularities: $\mathrm{K}>\mathrm{Ca}>\mathrm{P}>\mathrm{Mg}>\mathrm{Si}>\mathrm{Na}>\mathrm{Al}>\mathrm{Mn}>\mathrm{B}>\mathrm{Fe}>\mathrm{Zn}>$ $\mathrm{Ba}>\mathrm{Cu}>\mathrm{Cr}$ and $\mathrm{Se}>\mathrm{Co}>\mathrm{Sr}>\mathrm{Mo}>\mathrm{Cd}>\mathrm{Be}>\mathrm{Ni}>\mathrm{I}$.

2. Results of studying of element composition of the Verbena officinalis L. herb and samples of soil from different areas of plants growing in Ivano-Frankivsk and Ternopil regions show that quantitative and qualitative composition of macro- and microelements depends on the element exchange of these plants, conditions of growing, element composition of soil. The reverse dependence between the content of most elements in soil and the Verbena officinalis L. herb was determined.

3. The conducted comparative study of the element composition of Verbena officinalis L. herb, Verbena officinalis L. herb extracts VOH-0 and VOH-7 allowed us to define the transition of elements from plant raw material. It was found out that concentration of elements in the herb and extracts had the same profile, but the quantitative content of elements was different, which was influenced by the character of the extractant. Results of our research are currently relevant; they should be taken into account during the development of new medicines of herbal origin, which would have desirable pharmacological effect.

It is prospective to conduct further experimental pharmacological research of the Verbena officinalis L. herb as a medicinal plant raw material, which demonstrates anti-inflammatory, hepatoprotective and antimicrobial effect.

\section{References}

Bashkirova LM (2006) Biological function of essential macro- and microelements. Drugs of Ukraine 3: 59-64.

DSTU ISO [11885: 2005] (2007) Water quality. Determination of 33 elements by the method of atomic emission spectrometry with inductively coupled plasma. Derzhspozhyvstandart, Kyiv, 14 pp. https:// www.iso.org/standard/36250.html

Gupta UC, Gupta SC (2014) Sources and deficiency diseases of mineral nutrients in human health and nutrition: a review. Pedosphere 24 (1): 13-38. https://doi.org/10.1016/S1002-0160(13)60077-6

Hrodzinskyi AM (1990) Medicinal plants: encyclopedic guide. Kyiv, 165-167. https://choice.nethouse.ua/static/ doc/0000/0000/0130/130136.3q46zv2ro8.pdf

Hrynkevych NY, Safronych LN (1983) Chemical analysis of medicinal plants. Higher school, Moscow. http://booksonchemistry.com/books/ analit-him/ladigina-eya/1983/files/himanalizlekrasteniy1983.pdf

Nesom G (2010) Infrageneric classification of Verbena (Verbenaceae). Phytoneuron: 1-15. http://www.phytoneuron.net/PhytoN-Verbclassification.pdf

Kazi TG, Afridi HI, Kazi N, Jamali MK, Arain MB, Jalbani N, Kandhro GA (2010) Copper, chromium, manganese, iron and zinc levels in biological samples of diabetes mellitus patients. Biological Trace Element Research 122: 1-18. https://doi.org/10.1007/s12011-0078062-y

Kozyra SA, Kulahina MA, Radko OV, Serbin AH (2011) Research of macro- and microelement composition of Geum urbanum L. raw material. Actual issues of pharmaceutical and medical science and practice XXIV, No. 3.: 36-37.

Kvashnina LV, Rodionov VP, Rachkovska VV (2009) Micro- and macroelement homeostasis of dismicroelementosis in childhood. Perinatology and Pediatrics 3: 91-95.
Markevych VE, Hlushchenko NV (2010) Peculiarities of microelement and energetic provision of children, $1^{\text {st }}$ type diabetes patients. Visnyk SumSU. Series Medicine 1: 112-122.

Maliuvanchuk SV, Stasiv TH, Hrytsyk AR, Struk OA (2018) The study of macro- and microelementi composition of medicinal plants raw materials of Aiuga reptans L. and Filipendula hexapetala Gilib. Pharmacia 65(4): 38-45. https://elibrary.ru/item.asp?id=38688832

Nischwitz V, Mogwasi R, Zor S, Getenga Z, Kariuki DK, Günther K (2014) First comprehensive study on total contents and hot water extractable fraction of selected elements in 19 medicinal plants from various locations in Nyamira County. Journal of Trace Elements in Medicine and Biology 39: 54-61. https://doi.org/10.1016/j. jtemb.2016.08.001

Pasichnyk HI, Maiorova Olu, Voitiuk VB, Hrytsak LR (2011) Content of some macro- and microelements in soils and plants of Gentiana lutea L. of both Chornohirska populations of the Ukrainian Carpathians. Naukovyi visnyk. Uzhhorod. Series Biology 30: 183-187. https://dspace.uzhnu.edu.ua/jspui/bitstream/lib/5437/1/\%D0\%92\%D0\%9C\%D0\%86\%D0\%A 1\%D0 \%A2 \% 20\%D0 \% 94\%D0 \% 95\%D0\%AF\%D0\%9A\%D0 \% 98\%D0 \%A $\% 20 \%$ D0 \% 9 C \%D0\%90\%D0\%9A\%D0\%A0\%D0\%9E-\% 20 \%D0\%86\%20\%D0\%9C\%D0\%86\%D0\%9A\%D0\%A0\%D0\%9E\%D 0\%95\%D0\%9B\%D0\%95\%D0\%9C\%D0\%95\%D0\%9D\%D0\%A2\% D0\%86\%D0\%92\%20\%D0\%A3\%20\%D2\%90\%D0\%A0\%D0\%A3\% D0\%9D\%D0\%A2\%D0\%90\%D0\%A5\%20\%D0\%A2\%D0\%90\%20 \%D0\%A0\%D0\%9E\%D0\%A1\%D0\%9B\%D0\%98\%D0\%9D\%D0\%90 $\%$ D0\%A5.pdf

Perekhodko OM (2015) Research of dependences of the content of chemical elements in the roots and leaves of Convallaria majalis L. on forestry and taxonic indicators of forest and plant conditions. Naukovyi visnyk 
NNLTU of Ukraine: a collection of scientific technical works. Lviv: RVV NLTU of Ukraine 236: 45-51. https://cyberleninka.ru/article/n/ doslidzhennya-zalezhnostey-vmistu-himichnih-elementiv-u-korinni-ta-listi-roslin-konvaliyi-zvichaynoyi-convallaria-majalis-l-vid/viewer Pohorielov MV, Bumeister VI, Tkach HF (2010) Macro- and microelements (metabolism, pathology and methods of identification). Sumy: Edition SumSU, 147 pp. https://essuir.sumdu.edu.ua/handle/123456789/2727

Posatska NM, Hrytsyk AR (2017) Nature treats... Distribution and prospectives of Verbena genus species in medicine and pharmacy: Monograph. Ivano-Frankivsk, $55 \mathrm{pp}$.
State Pharmacopoeia of Ukraine: in 3 volumes (2015) SE "Ukrainian Scientific Pharmacopoeial Centre of Drugs Quality”. $2^{\text {nd }}$ edn. State enterprise "Ukrainian Scientific Pharmacopoeial Centre of Drugs Quality” (Vol. 1). Kharkiv.

Shakya AK (2016) Medicinal plants: future source of new drugs. International journal of herbal medicine 4(4): 59-64. http://www.florajournal.com/archives/2016/vol4issue4/PartA/4-2-13-120.pdf

Trzhetsynskyi SD et al. (2015) Training methodical textbook for the $5^{\text {th }}$ year full-time students of Pharmaceutical Faculty. Resource study / Zaporizhzhia. 